\author{
St ud i P hiloso phic a \\ Wr a t is l a vi e n s i a \\ vol. XIV, fasc. 4 (2019) \\ DOI: $10.19195 / 1895-8001.14 .4 .5$
}

\author{
MARCIN DROFISZYN \\ ORCID: 0000-0003-0518-5721 \\ Uniwersytet Wrocławski
}

\title{
Zasada aglomeracji i dylematy moralne
}

\section{A Deontic Logic for Normative Dilemmas}

\begin{abstract}
Standard deontic logic does not tolerate normative conflicts. If we assume that one ought to do A and ought to do B, but cannot do them both, we get a contradiction within deontic logic. Philosophers who deny that there could be genuine moral dilemmas treat this fact as the proof that dilemmas are logically impossible. At the same time, the advocates of the possibility of moral dilemmas propose to reject or restrict standard deontic principles. What consequences does it have for the resulting logic? Some of them are too strong because they contain the theorem of normative triviality or "deontic explosion," which says that if there is any case of normative conflict, then everything is obligatory. On the other hand, some of them are too weak, since they are not able to validate more important deontic inferences (especially the Smith Argument). Lou Goble introduces three criteria of adequacy that any deontic logic should meet if it is to accommodate normative conflicts successfully. First, I present these conditions and then I introduce a new logic of ought that fully meets all of them.
\end{abstract}

Keywords: deontic logic, moral dilemmas, agglomerative principle

(1) W filozofii rzadko dochodzi do porozumienia w kwestii ustalenia istoty rozpatrywanego fenomenu, jednak na temat istoty dylematu moralnego istnieje względna zgoda. Filozofom udało się sformułować definicję, którą określa się jako standardową. Definicja ta za dylemat pozwala uznać każdą sytuację, w której podmiot działający staje przed moralnym obowiązkiem wykonania dwóch czynów, które nie mogą być jednocześnie zrealizowane. A jeśli zamiast o obowiązkach i czy- 
nach mówić o powinnościach i stanach rzeczy, to istotę dylematu można wyrazić jako konflikt dwóch powinności, które nie mogą być jednocześnie spełnione. Realizacja jednej z powinności przekłada się na zaniechanie drugiej.

O ile w kwestii definicji dylematu udało się osiągnąć względny konsensus, o tyle pytanie o możliwość istnienia rzeczywistych dylematów moralnych budzi znacznie więcej kontrowersji. Dla osoby niezajmującej się filozofią moralną na poziomie akademickim postawienie pytania o możliwość istnienia dylematów wydaje się kuriozalne. Dylematów doświadcza każdy i jest to na tyle bolesne doświadczenie, żeby jasno uzmysłowić sobie uwikłanie w tego rodzaju sytuację. Filozofowie argumentujący przeciw możliwości istnienia dylematów odpowiadają, że to, co doświadczamy jako dylemat, nie spełnia in extenso definicji dylematu. To, co wydaje się dylematem moralnym może nim nie być, jeśli choć jedna z powinności skonfliktowanych nie ma charakteru powinności moralnej. Albo to, co wydaje się nam sytuacją bez wyjścia na gruncie teorii etycznej ma swoje rozstrzygnięcie. Gdybyśmy tylko zupełnie poznali inferencje logiczne naszych przekonań moralnych, a ponadto byli dogłębnie poinformowani co do istotnych aspektów problematycznej sytuacji i byli na tyle roztropni, aby mieć świadomość, które szczegółowe kwestie podpadają pod które ogólne normy, wówczas nie mielibyśmy problemu z sytuacją, w którą jesteśmy uwikłani. Jednym słowem, przeciwnicy dylematów ich źródła dopatrują się jedynie w ograniczeniach poznawczych podmiotu.

Zwolennicy istnienia dylematów twierdzą, że problem tkwi znacznie głębiej aniżeli jedynie na poziomie epistemicznym. Możemy mieć do czynienia ze skonfliktowanymi powinnościami, za którymi stoją niewspółmierne wartości. Ich problematyczność brałaby się z niemożliwości ustalenia na jednej skali, którym wartościom należałoby dać pierwszeństwo w realizacji. Albo jedna i ta sama wartość może domagać się działań niemożliwych do jednoczesnej realizacji, wówczas mielibyśmy do czynienia z symetrycznymi opcjami ${ }^{1}$.

Zwolennicy dylematów są w tej komfortowej sytuacji, że ich naczelna teza ma charakter egzystencjalny — istnieją rzeczywiste dylematy. Aby więc dowieść jej zasadności, wystarczy wskazać choć jeden przykład sytuacji spełniającej odnośne warunki: dylemat wynikający z symetrycznych opcji lub niewspółmiernych wartości. Jest wiele prób sprostania temu zadaniu. Zwolennicy odwołują się do wielu przykładów literackich: Antygony, Agamemnona, przykładu studenta podanego przez J.P. Sartre'a czy dramatycznego wyboru opisanego w powieści W. Styrona Wybór Zofii. Rozpatruje się również współczesne przypadki rozdzielenia sióstr Syjamskich Jodie i Joli albo dowódców Pentagonu deliberujących nad zestrzeleniem samolotu pasażerskiego porwanego przez terrorystów.

Przeciwnicy dylematów każdy taki przypadek pokazują w świetle sobie właściwej tezy. Dowodzą, jak można rozstrzygnaćc dany kazus albo uzasadniają, w jaki sposób nie spełnia on w pełni definicji dylematu moralnego. Przeciwnicy dylematów nie ograniczyli się jednak tylko do roli negatywnej — dyskredytowania argumentów przeciwnika. Przedstawili argument na tyle ogólnej natury, aby móc

\footnotetext{
${ }^{1}$ Szerzej temat omawia B. Chyrowicz, O sytuacjach bez wyjścia w etyce. Dylematy moralne: ich natura, rodzaje i sposoby rozstrzygania, Kraków 2008, s. 176-207.
} 
wykazać niemożliwość istnienia rzeczywistych dylematów a priori. W myśl tego argumentu przyjęcie założeń o możliwości dylematu prowadzi do poważnych trudności logicznych. Ponieważ całe rozumowanie przeprowadza się na gruncie logiki deontycznej, dlatego można ten argument nazwać argumentem z logiki deontycznej przeciwko możliwości istnienia dylematów moralnych. Dalej przedstawię go w szczegółach. W tym celu należy wprowadzić aparat formalny logiki deontycznej.

(2) Zbiór formuł poprawnie zbudowanych dla języka logiki deontycznej L budujemy w standardowy sposób przez wyszczególnienie alfabetu, a następnie podanie reguł składni. Na alfabet składają się:

(i) przeliczalnie wiele liter zdaniowych p, q, r...,

(ii) symbole spójników logicznych $\sim, \rightarrow, \vee, \wedge, \equiv$, odpowiednio dla negacji, implikacji materialnej, alternatywy, koniunkcji i równoważności materialnej,

(iii) jednoargumentowy operator modalny $\mathrm{O}$, który czytamy „powinno być tak, że" (,jest powinne to, że")

(iv) symbole pomocnicze ), (.

Zbiór formuł poprawnie zbudowanych to najmniejszy zbiór G spełniajaccy warunki:

(i) $p, q, r \ldots \in G$,

(ii) jeśli $\alpha, \beta \in \mathrm{G}$, to $\sim \alpha \in \mathrm{G}, \alpha \rightarrow \beta \in \mathrm{G}, \alpha \vee \beta \in \mathrm{G}, \alpha \wedge \beta \in \mathrm{G}, \alpha \equiv \beta \in \mathrm{G}$, $\mathrm{O} \alpha \in \mathrm{G}$.

W dalszej części litery $\alpha, \beta, \gamma \ldots$ będą zastępować poprawnie zbudowane formuły języka $L$.

Za pomocą skrótu definicyjnego:

(DEF-P) $\mathrm{P} \alpha \equiv \mathrm{df} \sim \mathrm{O} \sim \alpha$,

wprowadzamy operator modalny P, który czytamy , jest dozwolone to, że".

Warunki dylematu można teraz sformułować w języku L następująco:

(i) $\mathrm{O} \alpha$,

(ii) $\mathrm{O} \beta$,

(iii) $\sim \mathrm{P}(\alpha \wedge \beta)$.

Dylemat to przypadek gdy zarazem powinno być tak, że $\alpha$, powinno być tak, że $\beta$, a przy tym nie jest dozwolona koniunkcja $\alpha \wedge \beta$. Formalizacja warunku (iii) wymaga komentarza, ponieważ odbiega od tego, jak jest zapisywany w literaturze, począwszy od klasycznej pracy Davida O. Brinka². Tradycyjnie stosuje się zapis $\sim \diamond(\alpha \wedge \beta)$, gdzie $\diamond$ jest aletycznym funktorem możliwości. Zastąpienie operatora aletycznego operatorem deontycznym wydaje się o tyle uzasadnione, że klasyczna definicja dylematu nie przesądza, o jaką niemożliwość zajścia koniunkcji $\alpha \wedge \beta$ może chodzić. Może to być niemożliwość fizyczna, by zrealizować jednocześnie $\alpha$ i $\beta$, a może to być niemożliwość normatywna, bo wybór do realizacji jednego członu przekłada się na zaniechanie drugiego, z czym wiąże się niesprostanie pewnemu wymogowi normatywnemu i tym samym zajście czegoś niedozwolonego moralnie. $W$ tym sensie $\alpha$ i $\beta$ nie są dopuszczalne deontycznie zarazem. Na pewno sugerowanie niemożliwości logicznej $\alpha$ i $\beta$ nie wydaje się bardziej uzasadnione niż

${ }^{2}$ D.O. Brink, Moral Conflict and Its Structure, [w:] Moral Dilemmas and Moral Theory, H.E. Mason (ed.), New York-Oxford 1996, s. 102-126. 
deontycznej, ponieważ w sformułowaniu definicji nie sugeruje się aż tak mocnej tezy, jakoby w żadnym świecie nie można by było sobie pomyśleć, aby dało się zrealizować zarazem $\alpha$ i $\beta$.

Zaproponowane uproszczenie, bo jest to de facto uproszczenie formalizacji warunków dylematu do języka logiki deontycznej, a nie do multimodalnego języka deontyczno-aletycznego, jest również uzasadnione przez fakt równej siły inferencyjnej obu formalizacji. Normalnie warunek $\sim \diamond(\alpha \wedge \beta)$ wraz z zasadą ,powinność implikuje możność", inaczej zwaną zasadą Kanta: $\mathrm{O} \alpha \rightarrow \diamond \alpha$, prowadzi do wniosku, że koniunkcja $\alpha$ i $\beta$ nie jest powinna: $\sim \mathrm{O}(\alpha \wedge \beta)$. Jeśli w logice deontycznej zasada Kanta jest wyrażona przez zasadę $\mathrm{D}: \mathrm{O} \alpha \rightarrow \sim \mathrm{O} \sim \alpha$, ponieważ w innym sformułowaniu może być odczytana, że sytuacje niemożliwe logicznie nie są powinne $\sim \mathrm{O}(\alpha \wedge \sim \alpha)$, to z warunku $\sim \mathrm{P}(\alpha \wedge \beta)$ poprzez zasadę $\mathrm{D}: \mathrm{O} \sim(\alpha \wedge \beta) \rightarrow \sim \mathrm{O}(\alpha \wedge \beta)$, również dochodzimy do wniosku: $\sim \mathrm{O}(\alpha \wedge \beta)$.

Zobaczymy teraz, jak warunki (i)-(iii) prowadzą do sprzeczności na gruncie zupełnie elementarnego systemu logiki deontycznej. System ten nazywany jest standardowym systemem logiki deontycznej, ponieważ zawiera tak elementarne zasady, że każda teoria norm pretendująca do miana teorii racjonalnej powinna respektować jej zasady. Przypomnijmy: na system standardowy, który tu będziemy oznaczać skrótem SLP, składają się wszystkie formuły języka L o postaci:

(Taut) $\alpha$, gdzie $\alpha$ jest formułą będącą podstawieniem dowolnej tautologii klasycznego rachunku zdań,

(K) $\mathrm{O}(\alpha \rightarrow \beta) \rightarrow(\mathrm{O} \alpha \rightarrow \mathrm{O} \beta)$

(D) $\mathrm{O} \alpha \rightarrow \sim \mathrm{O} \sim \alpha$,

oraz powstające przez zastosowanie do powyższych jednej z reguł inferencji:

(MP) $\alpha \rightarrow \beta, \alpha / \beta$,

$(\mathbf{R M}) \alpha \rightarrow \beta / \mathrm{O} \alpha \rightarrow \mathrm{O} \beta$.

Tezami systemu standardowego są między innymi:

(AP) $\mathrm{O} \alpha \wedge \mathrm{O} \beta \rightarrow \mathrm{O}(\alpha \wedge \beta)$

$(\mathbf{Z E}) \sim \mathrm{P}(\alpha \wedge \beta) \wedge \mathrm{O} \alpha \rightarrow \mathrm{O} \sim \beta$,

$(\mathrm{DEX})(\mathrm{O} \alpha \wedge \mathrm{O} \sim \alpha) \rightarrow \mathrm{O} \beta$,

$(\mathrm{N}) \mathrm{O}(\alpha \wedge \beta) \rightarrow(\mathrm{O} \alpha \wedge \mathrm{O} \beta)$

$($ MTP $) \mathrm{O}((\alpha \vee \beta) \wedge \sim \alpha) \rightarrow \mathrm{O} \beta$.

Możemy teraz zobaczyć, jak przyjęcie założeń o możliwości dylematu prowadzi do sprzeczności na gruncie logiki deontycznej SLP.
1. $\mathrm{O} \alpha$,
2. $\mathrm{O} \beta$,
3. $\sim \mathrm{P}(\alpha \wedge \beta)$,
4. $\mathrm{O} \sim(\alpha \wedge \beta)$,
5. $\mathrm{O} \alpha \wedge \mathrm{O} \beta \rightarrow \mathrm{O}(\alpha \wedge \beta)$,
6. $\mathrm{O}(\alpha \wedge \beta)$,
7. $\mathrm{O}(\alpha \wedge \beta) \rightarrow \sim \mathrm{O} \sim(\alpha \wedge \beta)$,
8. $\sim \mathrm{O} \sim(\alpha \wedge \beta)$.

założenie

założenie

założenie

(DEF-P) i 3

twierdzenie (AP)

$\mathrm{z} 1,2$ i 5

aksjomat (D)

$z 6 i r$ 
Niektórzy kwestionują zasadność twierdzenia (AP), o czym napiszę dalej. Można je w tym rozumowaniu zastąpić formułą (ZE), którą Bogusław Wolniewicz nazwał zasadą Elzenberga ${ }^{3}$. Mianowicie:

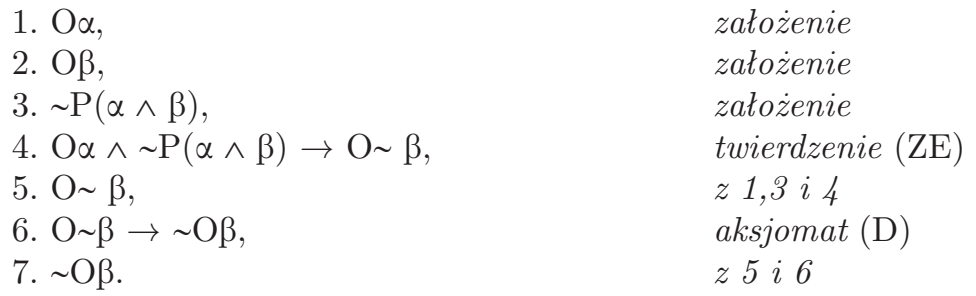

(3) Rozwiązaniem problemu sprzeczności w systemie logiki deontycznej przy założeniu zachodzenia dylematu moralnego wydaje się z kilku powodów tout court odrzucenie aksjomatu (D). Po pierwsze, aksjomat ten wyklucza możliwość, aby powinne były zarazem $\alpha$ jak i $\sim \alpha$, czyli jest równoważny postaci $\sim(\mathrm{O} \alpha \wedge \mathrm{O} \sim \alpha)$, a warunki dylematu (i)-(ii) redukują się na gruncie systemu SLP do postaci

(i) $\mathrm{O} \alpha$,

(ii) $\mathrm{O} \sim \alpha$,

co można łatwo dostrzec w powyższym rozumowaniu (kroki od 1 do 5). Widać to również od strony semantycznej. Aksjomat (D) w semantyce relacyjnej jest spełniony w serialnej klasie modeli, czyli w takich modelach, gdzie nie ma światów bezalternatywnych. Jeśli nie ma światów bezalternatywnych (tak zwanych ślepych końców), to można uznać, że nie ma sytuacji bez wyjścia. Ponadto Alan R. Anderson, podejmując próbę redukcji logiki deontycznej do logiki aletycznej ${ }^{4}$, przy definicji $\mathrm{O} \alpha \equiv \mathrm{Q}(\mathrm{S} \rightarrow \alpha)$ ( $\alpha$ jest powinne, to tyle co $\alpha$ z konieczności wynika z kodeksu norm S), pokazał, że aksjomat (D) jest równoważny zasadzie $\diamond$ S, którą można odczytać — kodeks normatywny nie jest sprzeczny.

Wszystkie te fakty świadczą o tym, że aksjomat (D) jest głównym filarem podtrzymującym argument o sprzeczności w systemie logicznym, jeśli by przyjąć warunki dylematu. A zatem, jak można skonstatować, aksjomat (D) ogranicza ze swej istoty stosowalność logiki deontycznej jedynie do struktur norm bez dylematów. Może więc wystarczy odrzucić ten aksjomat, aby argument z logiki deontycznej w kwestii możliwości istnienia dylematów stracił swoją ważność? Niestety bez aksjomatu (D) warunki dylematu maja nieakceptowane konsekwencje dla teorii etycznej, w ramach której zostają przyjęte. Spójrzmy:
1. $\mathrm{O} \alpha$,
założenie
2. $\mathrm{O} \beta$,
założenie
3. $\sim \mathrm{P}(\alpha \wedge \beta)$,
założenie
4. $\mathrm{O} \sim(\alpha \wedge \beta)$,
(DEF-P) $i 3$
5. $\mathrm{O} \alpha \wedge \mathrm{O} \beta \rightarrow \mathrm{O}(\alpha \wedge \beta)$,
twierdzenie (AP)
6. $\mathrm{O}(\alpha \wedge \beta)$,
$z 1$, 2 i 5
7. $\mathrm{O}(\alpha \wedge \beta) \wedge \mathrm{O} \sim(\alpha \wedge \beta) \rightarrow \mathrm{O} \gamma$,
8. $\mathrm{O} \gamma$.
twierdzenie (DEX)
$z 4,6 i 7$

\footnotetext{
${ }^{3}$ B. Wolniewicz, Myśl Elzenberga, ,Studia Filozoficzne” 12 (1986), s. 64.

${ }^{4}$ A.R. Anderson, A Reduction of Deontic Logic to Alethic Modal Logic, ,Mind” 67 (1958), s. 100-103.
} 
Założenie o dylemacie doprowadziło nas do wniosku: powinno być tak, że $\gamma$, gdzie $\gamma$ reprezentuje dowolną formułę języka L. Można to odczytać, że w sytuacji dylematu wszystko staje się powinne. Kiedy zaś wszystko jest powinne, to nic nie jest zabronione lub obojętne. Wszelkie dystynkcje moralne upadają, teoria etyczna staje się trywialna. Taką sytuację zwykło nazywać się eksplozją deontyczną (deontic explosion), można też powiedzieć o deontycznym przepełnieniu teorii.

Nawiasem mówiąc z tego rozumowania można wykluczyć twierdzenie (AP):
1. $\mathrm{O} \alpha$,
2. $\mathrm{O} \beta$,
założenie
3. $\sim \mathrm{P}(\alpha \wedge \beta)$,
założenie
4. $\mathrm{O} \alpha \wedge \sim \mathrm{P}(\alpha \wedge \beta) \rightarrow \mathrm{O} \sim \beta$,
5. $\mathrm{O} \sim \beta$,
6. $(\mathrm{O} \beta \wedge \mathrm{O} \sim \beta) \rightarrow \mathrm{O} \gamma$,
7. $\mathrm{O} \gamma$.
założenie
twierdzenie $(\mathbf{Z E})$
$z 1,3 i 4$
twierdzenie (DEX)
$z 2,5$ i 6

Problem deontycznej eksplozji wynika z tego, że tezą systemu standardowego jest formuła (DEX): $(\mathrm{O} \alpha \wedge \mathrm{O} \sim \alpha) \rightarrow \mathrm{O} \beta$. Jest ona prostym następstwem tautologii klasycznego rachunku zdań (EFQ): $(\alpha \wedge \sim \alpha) \rightarrow \beta$, zwanej ex falsum quodlibet (do dowodu wykorzystuje się (N) i (RM)). Oczywiście istnieje teoretyczna możliwość odrzucenia tej tautologii i kilku autorów podjęło się tego zadania, budując systemy logiki deontycznej na bazie logik parakonsystentnych ${ }^{5}$. Jest to jednak zbyt radykalne odejście od standardowej logiki, dlatego nie będę dalej zagłębiać się w tego typu badania, uznając je za ciekawe teoretyczne rozważania omawianego problemu.

Skoro odrzucenie aksjomatu (D) nie jest dobrym rozwiązaniem problemu sprzeczności systemu logiki deontycznej przy założeniu dylematu moralnego, więc może mniej problematyczne będzie odrzucenie aksjomatu $(\mathbf{K})$, ponieważ dzięki temu tezami systemu przestaną być formuły (AP) i (ZE). Bez twierdzeń (AP) i (ZE) nie odtworzymy dowodu sprzeczności ani deontycznego przepełnienia w systemie standardowym wzbogaconym o warunki dylematu. Taką logikę dla dylematów postuluje na przykład Brian F. Chellas jako minimalną logikę deontyczną ${ }^{6}$. Niestety i to rozwiązanie obarczone jest poważnym mankamentem. Systemy logiki bez (K) mają bardzo małą moc inferencyjną. W szczególności nie uchwytują podstawowych wnioskowań między normami, które uważamy za oczywiste. Swoistym probierzem funkcjonującym w literaturze przedmiotu tego, czy teoria logiczna ma dostateczną moc inferencyjną jest uzasadnianie przez nią następującego rozumowania, zwanego Argumentem Smitha ${ }^{7}$ :

${ }^{5}$ Zob. np. N.D. Costa, W. Carnielli, On Paraconsistent Deontic Logic, „Philosophia” 16 (1986), s. 293-305; R. Routley, V. Plumwood, Moral Dilemmas and the Logic of Deontic Notions, [w:] Paraconsistent Logic: Essays on the Inconsistent, G. Priest, R. Routley, J. Norman (eds.), Munich 1989, s. 653-690; L. Goble, Deontic Logic with Relevance, [w:] Norms, Logics and Information Systems. New Studies on Deonic Logic and Computer Science, P. McNamara, H. Prakken (eds.), Amsterdam 1999, s. 331-345; M. Beirlæn, Ch. Straßer, J. Meheus, An Inconsistency - Adaptive Deontic Logic for Normative Conflicts, ,Journal of Philosophical Logic” 42 (2013), s. 285-315.

${ }^{6}$ B.F. Chellas, Modal Logic. An Introduction, Cambridge 1980, s. 202.

${ }^{7}$ Argument sformułowany przez J.F. Horty w artykule Moral Dilemmas and Nonmonotonic Logic, „Journal of Philosophical Logic” 23 (1994), s. 39. 
(i) Smith powinien odbyć służbę wojskową lub podjąć służbę zastępczą dla swojego kraju (formalizujemy: $O(\alpha \vee \beta)$ ).

(ii) Smith powinien uniknąć służby wojskowej, na przykład ze względu na swoje pacyfistyczne przekonania $(\mathrm{O} \sim \alpha)$.

(iii) A zatem: Smith powinien podjąć służbę zastępczą (Oß).

$\mathrm{Na}$ gruncie systemu standardowego logiki deontycznej z przesłanek (i) i (ii) przechodzimy do wniosku (iii) w sposób następujący:

1. $\mathrm{O}(\alpha \vee \beta) \wedge \mathrm{O} \sim \alpha \rightarrow \mathrm{O}((\alpha \vee \beta) \wedge \sim \alpha)$,

2. $\mathrm{O}((\alpha \vee \beta) \wedge \sim \alpha)$,

twierdzenie (AP)

3. $\mathrm{O}((\alpha \vee \beta) \wedge \sim \alpha) \rightarrow \mathrm{O} \beta$, $z$ (i), (ii) $i 1$

4. $\mathrm{O} \beta$. twierdzenie (MTP) $z 2 i 3$

Dotychczasowa dyskusja prowadzi do wniosku o stosunkowo silnej mocy perswazyjnej argumentu z logiki deontycznej przeciwko możliwości przyjęcia dylematu moralnego na gruncie racjonalnej teorii etycznej, czyli takiej, która spełnia zasady co najmniej standardowego systemu logiki deontycznej. Przyjęcie założeń istnienia dylematu na gruncie i tak stosunkowo słabego systemu logiki deontycznej prowadzi do sprzeczności, a wiadomo, że jest to cecha, która dyskryminuje system, ponieważ sprzeczność prowadzi na mocy tautologii (EFQ) do przepełnienia — teza staje jest każda formuła. Kolejne osłabianie systemu standardowego, aby uwolnić się od tej trudności, prowadzi wciąż do przykrych konsekwencji. Odrzucenie aksjomatu (D) prowadzi do innej formy przepełnienia - przy warunkach dylematu tezą staje się każda formuła poprzedzona operatorem O. Z kolei odrzucenie aksjomatu (K) prowadzi do osłabienia systemu standardowego do tego stopnia, że nie uzasadnia elementarnych wnioskowań normatywnych.

(4) Ponieważ sprostanie argumentowi z logiki deontycznej przeciwko możliwości istnienia dylematów moralnych jest w interesie grupy filozofów określających się jako zwolennicy ich istnienia, dlatego ważnym zadaniem teoretycznym jest rozważenie problemu, jak miałaby wyglądać logika deontyczna dopuszczająca możliwość dylematów, ale unikająca przykrych konsekwencji. Taki problem teoretyczny explicite postawił niedawno Lou Goble ${ }^{8}$. Wyzwanie Gobla polega na zaproponowaniu logiki deontycznej, elementarnego rodzaju, czyli nadbudowanej nad klasycznym rachunkiem zdań, która dopuszcza możliwość dylematu, a przy tym spełnia warunki:

1. Unika sprzeczności (warunek niesprzeczności).

2. Unika deontycznej eksplozji (warunek nietrywialności).

3. Uzasadnia Argument Smitha (warunek siły).

Dalej w pracy podejmę to wyzwanie. Abstrahując od szczegółowych kwestii związanych z dyskusją zwolenników i przeciwników dylematów, zapytam, jak miałaby wyglądać logika deontyczna dla dylematów. Już z czysto teoretycznego punktu widzenia, bez opowiadania się za jedną ze stron, interesującą kwestią jest, jak miałaby wyglądać logika powinności elementarnego rodzaju, która, nie będąc ograniczona jedynie do formuł bezkonfliktowych, spełnia warunki 1-3.

${ }^{8}$ Zob. L. Goble, A Logic for Deontic Dilemmas, „Journal of Applied Logic” 3 (2005), s. 461-483; L. Goble, Normative Conflicts and The Logic of „Ought”, „Noûs” 43 (2009), s. 450-489. 
L. Goble podjął próbę rozwiązania postawionego przez siebie problemu. W pracy A Logic for Deontic Dilemmas przedstawił trzy systemy DPM.1, DPM.2 i DPM. $3^{9}$. Dla celów dalszej dyskusji wystarczy przywołać jeden z nich — DPM.3, ponieważ zawiera aksjomaty wspólne dla dwóch pozostałych.

Aksjomatami DPM.3 są podstawienia tautologii KRZ oraz wszystkie formuły o postaci:

$(\mathrm{N})$

(PAND) $\quad \mathrm{P}(\alpha \wedge \beta) \rightarrow(\mathrm{O} \alpha \wedge \mathrm{O} \beta \rightarrow \mathrm{O}(\alpha \wedge \beta))$.

Reguły inferencji to:

(RPM) $\quad \alpha \rightarrow \beta / \mathrm{P} \alpha \rightarrow(\mathrm{O} \alpha \rightarrow \mathrm{O} \beta)$,

(RE) $\quad \alpha \equiv \beta / \mathrm{O} \alpha \equiv \mathrm{O} \beta$.

System DPM.3, podobnie jak pozostałe dwa, linearnie rzecz biorąc, spełnia postawione warunki: brak formuły (D) wyklucza sprzeczność, a ograniczona zasada aglomeracji (PAND) wyklucza deontyczną eksplozję oraz zabezpiecza argument Smitha, jeśli dodać entymematyczną przesłankę $\mathrm{P}(\sim \alpha \wedge \beta)$, którą można odczytać, że dozwolone jest uniknięcie służby wojskowej i odbycie służby zastępczej. Nie jest to jednak moim zdaniem zadowalające rozwiązanie tego problemu. Szukamy systemu logiki, który ma adaptować dylematy moralne, tymczasem Goble ogranicza kluczowe zasady swojego systemu do sytuacji bezkonfliktowych. Spójrzmy na zasadę aglomeracji (AP) w nowej postaci: (PAND). Jeśli $\alpha$ jest powinne i $\beta$ jest powinne, to powinna jest koniunkcja $\alpha$ i $\beta$, o ile koniunkcja $\alpha$ i $\beta$ jest dozwolona. Innymi słowy, to, co powinne osobno staje się powinne razem, o ile razem nie wchodzi z sobą w konflikt. Łatwo zauważyć, że w tej postaci (AP) nie może służyć do wykazania sprzeczności przy warunkach dylematu, bo się do nich po prostu nie stosuje.

Podobnie z regułą monotoniczności, zwaną również zasadą dziedziczenia. W wersji (RPM) można ją odczytać: jeśli $\alpha$ pociąga za sobą $\beta$, to jeśli powinno być tak, że $\alpha$, to powinno być tak że $\beta$, pod warunkiem że $\alpha$ jest dozwolone przez normatywny system. Innymi słowy: jeśli $\alpha$ jest powinnością nieskonfliktowaną i pociąga $\beta$, to $\beta$ jest również powinna. Przy tej postaci zasady (AP) nie jest tezą formuła (DEX), a więc nie ma deontycznej eksplozji, bo nie ma inferencyjnego przejścia od (EFQ) do (DEX) na mocy aksjomatu $(\mathbf{N}): \sim \mathrm{P}(\alpha \wedge \sim \alpha)$.

Goble, ograniczajac tezy swojego systemu do norm niebędących przesłankami w dylematach moralnych, rozwiązuje problem logiki deontycznej dla dylematów tylko połowicznie. Postuluje bowiem logikę dla dylematów moralnych, która nie stosuje się do dylematów. Powstaje coś na kształt logiki dla dylematów, ale bez dylematów. Tymczasem dla sytuacji bezkonfliktowych mamy już standardowy system logiki deontycznej i jego rozszerzenia. Sprostać wyzwaniu to pokazać, jak logika deontyczna ma wyglądać właśnie w sytuacjach konfliktowych. Postępowanie Gobla można przyrównać do zachowania przedstawiciela nauk empirycznych, który dla ratowania swojej teorii przed falsyfikacją zmienia zasięg stosowalności niektórych z praw składających się na tę teorię. Pytając takiego badacza o prawa wyjaśniające rzeczywistość, dostajemy prawa formułowane w dużym stopniu ad

${ }^{9}$ L. Goble, A logic for..., s. $474-478$. 
hoc, dla uniknięcia falsyfikacji. Podobnie w przypadku systemu DPM.3, pytając o logikę deontyczną dla teorii etycznej dopuszczającej dylematy, dostajemy system budowany ad hoc, jedynie aby uniknąć sprzeczności w przypadku ich zajścia.

Jest jeszcze jedna przykra konsekwencja dla systemu logiki deontycznej, jeśli ograniczyć jej niektóre zasady do sytuacji bezkonfliktowych. Nawiasem mówiąc, przedstawił ją D.O. Brink, zastanawiający się na długo przed Goblem, czy dla uniknięcia sprzeczności przy założeniach dylematu można ograniczyć stosowalność zasady aglomeracji właśnie do sytuacji bezkonfliktowych ${ }^{10}$. Otóż jeśli różne zasady będą się stosowały do powinności w kontekście dylematu i w kontekście bez dylematu, to różne zasady będą determinowały inne własności formalne powinności w tych dwóch różnych kontekstach. Zatem będzie można uznać, że powinność ma różne własności, a wręcz, że ma dwa różne znaczenia zależnie od kontekstu występowania ${ }^{11}$. Mówiąc najprościej, powinność w dylemacie stanie się inną powinnością niż poza dylematem.

Wobec tych mankamentów propozycji Gobla podejmę próbę własnego zmierzenia się z postawionym wyzwaniem. System, który zaprezentuję jako logikę deontyczną dla powinności dopuszczającej dylematy, będzie modyfikacją systemu LP. System LP zaprezentowałem w artykule Dylematy moralne $i$ logika deontyczna jako system, który omijając znane paradoksy logiki deontycznej, wykazuje sprzeczność warunków dylematu przy wykorzystaniu zupełnie elementarnych założeń typu zasada (D) i (ZE) ${ }^{12}$. System LP został więc zaprezentowany zupełnie w przeciwnym celu do tego, do którego zostanie użyty poniżej. Zanim omówię podstawowe modyfikacje na tym systemie, przypomnę jego aksjomaty i reguły inferencji.

(5) Zbiór tez systemu logiki powinności LP to najmniejszy zbiór zawierający jako aksjomaty wszystkie formuły języka L o postaci:

(TAUT) $\alpha$, gdzie $\alpha$ jest dowolną formułą będącą podstawieniem tautologii klasycznego rachunku zdań,

$\begin{array}{ll}(\mathbf{K}) & \mathrm{O}(\alpha \rightarrow \beta) \rightarrow(\mathrm{O} \alpha \rightarrow \mathrm{O} \beta), \\ (\mathbf{A P}) & \mathrm{O} \alpha \wedge \mathrm{O} \beta \rightarrow \mathrm{O}(\alpha \wedge \beta), \\ \left(\mathbf{M}^{*}\right) & \mathrm{O}(\alpha \wedge \beta) \rightarrow(\mathrm{O} \alpha \vee \mathrm{O} \beta), \\ (\mathbf{O D}) & \sim \mathrm{O}(\alpha \wedge \sim \alpha)\end{array}$

oraz domknięty na reguły inferencji:

(MP) regułę odrywania: $\alpha \rightarrow \beta, \alpha / \beta$,

(RE) regułę ekstensjonalności: $\alpha \equiv \beta / \mathrm{O} \alpha \equiv \mathrm{O} \beta$.

Aby uzyskać system logiki deontycznej dopuszczający dylematy moralne (oznaczmy go LP ${ }_{\mathrm{D}}$ ), dokonamy dwóch modyfikacji na systemie LP. Pierwsza modyfikacja to odrzucenie aksjomatu (OD). System dopuszczający dylematy nie

${ }^{10}$ D.O. Brink, op. cit., s. 114 .

${ }^{11}$ Brink pisze: „to już lepiej odrzucić takie zasady niż ograniczać ich zasięg” (ibidem, s. 114). Dziwi wobec tego przypisywanie Brinkowi propozycji osłabiania zasady aglomeracji do postaci: $(\mathrm{O} \alpha \wedge \mathrm{O} \beta$ $\wedge \sim \diamond(\alpha \wedge \beta)) \rightarrow \mathrm{O}(\alpha \vee \beta)$. Robi to J. Holbo w artykule Moral Dilemmas and the Logic of Obligation, „American Philosophical Quarterly” 39 (2002), s. 260.

12 M. Drofiszyn, Dylematy moralne $i$ logika deontyczna „Studia Philosophica Wratislaviensia” 3 (2019), s. $125-132$.

Studia Philosophica Wratislaviensia 14, z. 4, 2019

(C) for this edition by CNS 
może wykluczać jako powinnych sytuacji niemożliwych logicznie. W systemie $\mathrm{LP}_{\mathrm{D}}$ fałsze logiczne mogą więc być poprzedzone operatorem powinności.

Druga modyfikacja dotyczy aksjomatu aglomeracji (AP). Zamiast uznanej formy: $\mathrm{O} \alpha \wedge \mathrm{O} \beta \rightarrow \mathrm{O}(\alpha \wedge \beta)$, czyli to, co powinne osobno jest powinne razem, przybierze on słabszac postać: $\mathrm{O} \alpha \wedge \mathrm{O} \beta \rightarrow \mathrm{O}(\alpha \vee \beta)$, czyli to, co powinne osobno, może być powinne razem. Na system $L_{D}$ składają się więc następujące aksjomaty i reguły inferencji:

(TAUT) $\alpha$, gdzie $\alpha$ jest dowolną formułą będącą podstawieniem tautologii KRZ,

$(\mathrm{K})$

$\left(\mathrm{AP}^{*}\right)$

$\left(\mathrm{M}^{*}\right)$

(MP)

(RE)

$$
\begin{aligned}
& \mathrm{O}(\alpha \rightarrow \beta) \rightarrow(\mathrm{O} \alpha \rightarrow \mathrm{O} \beta), \\
& \mathrm{O} \alpha \wedge \mathrm{O} \beta \rightarrow \mathrm{O}(\alpha \vee \beta), \\
& \mathrm{O}(\alpha \wedge \beta) \rightarrow(\mathrm{O} \alpha \vee \mathrm{O} \beta), \\
& \alpha \rightarrow \beta, \alpha / \beta, \\
& \alpha \equiv \beta / \mathrm{O} \alpha \equiv \mathrm{O} \beta
\end{aligned}
$$

Modyfikacja zasady aglomeracji to zasadnicza zmiana w systemie LP. Dzięki zamianie funktora koniunkcji na funktor alternatywy $\mathrm{w}$ następniku tej formuły otrzymujemy system dopuszczający przyjęcie przesłanki o istnieniu dylematu moralnego. Ponieważ jednak zasada aglomeracji jest mocno utrwalona w literaturze przedmiotu $^{13}$, jako jedna z podstawowych tez logiki deontycznej, dlatego należy zadać sobie trud odpowiedzi na pytanie, czy zaproponowana modyfikacja nie ma charakteru jedynie takiej zmiany ad hoc, o której była mowa przy okazji krytyki propozycji Goble'a? Czy wprowadzenie zasady aglomeracji w nowej postaci ma jedynie uodpornić system LP na sprzeczność po przyjęciu przesłanki o istnieniu dylematu, czy też stoją za tym jakieś racje filozoficzne? Odpowiedzi na to pytanie udzielę w dwóch krokach. Po pierwsze, pokażę, że choć aksjomat ten należy do podstawowych tez systemu standardowego, to jednak ma grono krytyków. Po drugie, pokażę, że zaproponowana zmiana w znaczący sposób przybliża system logiki deontycznej do bardziej adekwatnego odzwierciedlenia formalnej struktury pojęcia powinności moralnej.

(6) Podobno pierwszy, który zwrócił uwage na kontrowersyjność zasady aglomeracji, był Bernard Williams. Williams zauważa, że działania można klasyfikować na wiele sposobów, poza tym, czy są powinne, czy nie. Jego zdaniem wśród tych klasyfikacji nie obowiązuje aglomeracja. Kiedy bowiem dwa różne działania uważam za sensowne, godne zalecenia czy pożądane, nie wyciągam z tego wniosku o byciu sensownym, godnym zalecenia czy pożądaniu obu tych działań zarazem. Rozumowanie przez analogię jest oczywiście zawodne, czego Williams jest świadom, niemniej jednak rzuca poważny cień wątpliwości na zasadność aglomeracji dla powinności ${ }^{14}$.

${ }^{13}$ Formuła ta należała do aksjomatów pierwszego systemu logiki deontycznej G.H. von Wrighta z 1951 roku (zob. D. Føllesdal, R. Hilpinen, Deontic logic. An Intoduction, [w:] Deontic logic: Introductory and Systematic Readings, R. Hilpinen (ed.), Dordrecht 1971, s. 11). Również w ostatnio wydanych opracowaniach logiki deontycznej zalicza się ją do podstawowych tez (zob. np. P. McNamara, Deontic Logic, [w:] Handbook of the History of Logic, D.M. Gabbay, J. Woods (eds.), t. 7, Nord-Holland 2006, s. 208; D. Rönnedal, An Introduction to Deontic Logic, Lexington 2017, s. 167).

${ }^{14}$ B. Williams, Spójność etyczna, tłum. M. Szczubiałka, [w:] idem, Ile wolności powinna mieć wola? I inne eseje z filozofii moralnej, tłum. T. Baszniak, T. Duliński, M. Szczubiałka, Warszawa 1999, s. 109. 
Wątpliwości względem tej zasady budzi dla Williamsa również sam fakt możliwości istnienia dwóch działań, z których każdy mogę i powinienem wykonać, ale których nie mogę wykonać zarazem. Skoro po połączeniu zatraca się możność wykonania obu, to nie powstaje powinność wykonania obu. Milczącą przesłanką jest tu łączenie powinności z możnością działania. Dla powinności czynów zwykło się przyjmować założenie o możliwości działania sprawcy zwanej zasadą woluntaryzmu albo inaczej zasadą Kanta. Powinność bytu może przejść na podmiot rozumny jako jego obowiązek, o ile ten jest na siłach, aby mu sprostać. Dlatego dla Williamsa wątpliwa jest zasada aglomeracji, bo z $\mathrm{O} \alpha$ i $\mathrm{O} \beta$ wynika $\mathrm{O}(\alpha \wedge \beta)$, nawet gdy nie można wykonać $\alpha \wedge \beta$, choć można wykonać $\alpha$ i można wykonać $\beta^{15}$.

Williams ma świadomość, że oba argumenty które podał przeciw zasadzie aglomeracji, nie mają jakiejś zniewalającej mocy przekonywania, niemniej swoje rozważania w tym temacie podsumowuje zastanawiającą konstatacją:

jestem zdania, że nie jest to bynajmniej oczywista dana logiki powinności i że jeśli za sprawą odrzucenia tej zasady powstaje bardziej realistyczny obraz refleksji moralnej, to nie powinniśmy mieć żadnych skrupułów przed jej odrzuceniem ${ }^{16}$.

Mamy tu do czynienia z rozumowaniem, które można rozwinacć do postaci bardziej rozbudowanej. Dylematy są nieodzowną częścią doświadczenia moralnego. Z istoty swej wikłają przekonania podmiotu w trudny do rozstrzygnięcia spór. A jeśli logika deontyczna, której zadaniem jest formalizowanie struktury przekonań moralnych, na podstawie kontrowersyjnej zasady aglomeracji wyklucza możliwość dylematów, to należałoby raczej odrzucić wątpliwą zasadę aglomeracji, niż wykluczyć możliwość dylematu.

Na zasadę woluntaryzmu przy krytyce zasady aglomeracji powołuje się również Ruth B. Marcus. Jeśli powinność ma się łączyć z możnością w tym sensie, że powinny czyn nie może być przypisany podmiotowi jako jego obowiązek, o ile podmiot nie może go zrealizować, to nie można z powinności dwóch czynów jednego sprawcy wnosić o powinności polegającej na ich łącznym wykonaniu, bo co można wykonać jako pojedynczy czyn, niekoniecznie może być wykonane wespół z innym. Marcus ma świadomość, że odrzucenie (AP) ,jest oczywiście odejściem od znanych systemów logiki deontycznej"17. Autorka zatem świadomie podejmuje się krytyki utrwalonej tradycji logicznej.

Zdaniem kolejnej badaczki kwestii możliwości istnienia dylematów moralnych, Mary Mothersill, zasada aglomeracji niefortunnie znalazła się wśród grona zasad logiki deontycznej przez przyjęcie zbyt daleko idącej analogii tej logiki do logiki modalnej. Paralela między zwrotami „konieczne” i „możliwe” a „obowiązkowe” i „dozwolone” nie sięga aż tak daleko, aby aglomerację, która obowiązuje dla pojęć aletycznych, rozciągać na pojęcia deontyczne.

Zdaniem Mothersill aglomeracja przeczy również naszym intuicjom potocznym związanym z klasyfikowaniem normatywnym. Oprócz powołania się na znaną nam

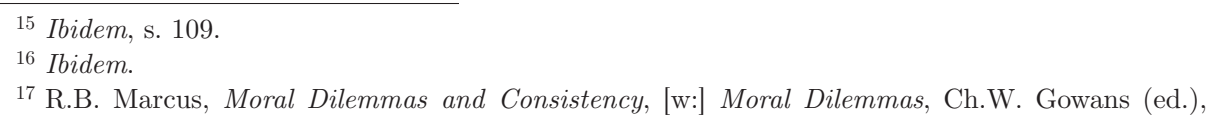
New York-Oxford 1987, s. 200. 
już zasadę woluntaryzmu autorka podaje jeszcze inny argument. Jak czytamy: ,jest w tym momencie co najmniej pięć rzeczy, które powinnam wykonać zamiast pisać ten tekst, ale nie wynika stąd, że powinnam teraz robić te pięć rzeczy oraz dodatkowo pisać ten tekst"18. Powinność tak jak rozumiemy ją na co dzień, nie ma własności kumulowania się — jeśli ktoś ma wiele obowiązków wyznaczonych w czasie, to nie oznacza to, że ma jeden obowiązek ich spełnienia zarazem w jakimś określonym czasie. Nie tak prowadzimy nasze myśli odnośnie do powinności, jak sugerowałaby zasada aglomeracji.

Moim zdaniem zaprezentowane głosy przeciw zasadzie aglomeracji skupiają się na tym, że aglomeracja nie stosuje się do powinności rozumianej jako obowiązek. Dla powinności bytu nie musi bowiem zachodzić zasada woluntaryzmu, gdyż dwa stany rzeczy, nawet przeciwne, mogą być bez problemu powinne w tym samym czasie do momentu, gdy nie szukamy możliwego podmiotu, który miałby wziąć na siebie ciężar realizacji tych powinności jako swoich obowiązków. Trudno obarczyć kogoś obowiązkiem, aby zrealizował to, co niemożliwe logicznie, czyli dwa przeciwne stany rzeczy. Ponadto dla powinności bytu nie ma również kłopotu z kumulacją $\mathrm{w}$ czasie. Wiele w tym samym czasie powinności może obejmować dany podmiot, ale ponieważ nie są jego obowiązkami, ten nie musi się podejmować ich realizacji w jakimś określonym terminie. Podkreśla to Elzenberg, pisząc, że powinność staje się obowiązkiem dopiero, gdy jest przypisana określonemu podmiotowi i określona co do czasu. Dopiero wtedy obowiązek jest wymagalny, czyli taki, że zaniechanie go pociąga za sobą ujemną ocenę moralną ${ }^{19}$. Zasada aglomeracji bardziej więc nadaje się do logik aksjologicznych lub formalizujących powinność pozamoralną.

(7) Jakie jednak przemawiają racje za przyjęciem zasady aglomeracji w zmienionej wersji (dla jasności wywodu nazwę ją osłabioną zasadą aglomeracji)? Tę postać aglomeracji dla powinności zaproponował D.O. Brink w artykule Moral Conflict and Its Structure. Brink przyznaje, że mamy tendencję do łączenia powinności w koniunkcję.

Skoro wierzę, że powinienem zrobić A i powinienem zrobić B, to nie tylko będę starał się unikać robienia rzeczy, które uniemożliwiają mi robienie jednego lub drugiego, ale będę starał się unikać robienia rzeczy, które uniemożliwiają mi robienie $\mathrm{obu}^{20}$.

I dalej pyta, czy z tego względu mogę wnosić, że mam obowiązek robienia obu tych rzeczy, tak jak mam obowiązek robienia każdej z nich. Odpowiada przecząco: „Wszystko co jest ode mnie wymagane to to, że mam dwa obowiązki i pragnienie spełnienia każdego, ale nie ma wymagania obowiązku koniunkcyjnego"21. To, że pragnę spełnić każdą powinność wokół siebie, sprawia, że łączę je w jeden obowiązek dla siebie. Jest to jednak nieuprawnione przejście w myśleniu na gruncie deontologii, a można się o tym przekonać, jeśli należycie odróżnimy powinności od obowiązków

\footnotetext{
18 M. Mothersill, The Moral Dilemmas Debate, [w:] Moral Dilemmas and..., s. 70.

${ }^{19}$ H. Elzenberg, Zagadnienie obowiazku w aksjologii formalnej, [w:] idem, Pisma aksjologiczne, Lublin 2002, s. 108-109.

${ }^{20}$ D.O. Brink, op. cit., s. 109.

${ }^{21}$ Ibidem.
} 
albo inaczej mówiąc, posługując się terminologią Williama D. Rossa, z której korzysta Brink, między obowiązkami prima facie a obowiązkami aktualnymi.

Obowiązki prima facie to inaczej obowiązki warunkowe. W danej chwili może wiele tego typu powinności być w zasięgu realizacji jakiegoś podmiotu, ale tylko jeden z nich staje się jego obowiązkiem aktualnym — ten mianowicie, który ze względu na ogół relewantnych okoliczności przezwycięża inne pod względem siły wiązania (dlatego inaczej obowiązki aktualne nazywa się obowiązkami uwzględniającymi całość moralnego kontekstu). Pozostałe obowiązki prima facie są ciągle powinnościami obowiązującymi, ale na szali ważności przegrywają z tym jednym jedynym $^{22}$. Co jednak zrobić, gdy pojawią się dwa obowiązki prima facie, które choć przezwyciężają wszystkie inne konkurujące, są między sobą w jakimś sensie nieporównywalne czy równie mocno ciążące i których jednocześnie nie da się zrealizować? Tak właśnie powstaje dylemat moralny. Brink uważa, że pytanie to jest źle postawione. Wystarczy dookreślić, jakie czynniki należy brać pod uwagę, aby móc przejść od obowiązku prima facie do obowiązku aktualnego. Zdaniem Brinka okolicznością istotną, którą również należy rozpatrzyć jest to, czy dany obowiązek warunkowy przezwycięża wszystkie inne. Jeśli konkuruje z jakimś innym, nie może stać się aktualnym. Jak czytamy:

taki obowiązek powinien brać wszystkie relewantnie moralnie fakty, włączając alternatywy. Tak więc, aby obowiązek prima facie był obowiązkiem uwzględniającym całość kontekstu (all-things-considered obligation) nie wystarczy aby nie był pokonany, ale musi również przezwyciężać wszystkie inne konkurencyjne ${ }^{23}$.

Jeśli obowiązek warunkowy nie przezwycięża wszystkich innych obowiązujących w danej chwili, to nie może stać się obowiązkiem aktualnym.

Co jednak w sytuacji, gdy dwa obowiązki prima facie równie mocno wiążą podmiot do działania, a przez to nie da się ustalić jednego obowiązku aktualnego? W takich okolicznościach podmiot zdaje się pozostawać bez żadnej dyrektywy działania. To jednak nieprawda — jak podkreśla Brink — w takich okolicznościach powstaje zupełnie nowy obowiązek bezwarunkowy: obowiązek działania w sytuacji dylematu moralnego. Tu dochodzimy do sedna uwagi Brinka. Otóż w obliczu dylematu: sprostać powinności A, czy powinności B, podmiot nie jest zobligowany do jednoczesnej realizacji A i B, tak jak tego wymaga zasada aglomeracji, ale jest zobligowany do zrobienia A lub B. Powstaje obowiązek wybrania i realizacji jednej ze skonfliktowanych opcji. Brink pisze tak:

nieprzezwyciężony obowiązek prima facie konstytuuje obowiązek uwzględniający-całość-kontekstu. Ale nie zawsze. Kiedy mamy do czynienia z nieprzezwyciężonym konkurentem, możemy wnosić że żaden obowiązek nie jest obowiązkiem uwzględniającym całość moralnego kontekstu. To może sprawiać wrażenie opuszczenia podmiotu bez obowiązków w obliczu nierozwiązywalnego konfliktu [...]. Ale podmiot staje wobec pewnego obowiązku uwzględniającego-całość-kontekstu: polega on na wykonaniu jednego lub drugiego ze skonfliktowanych prima facie obowiązków ${ }^{24}$.

${ }^{22}$ Szerzej omówione rozróżnienie obu rodzaju obowiązków np. w T. Hurka, British Ethical Theorists from Sidgwick to Ewing, New York-Oxford 2014, s. 69-78.

${ }^{23}$ D.O. Brink, op. cit., s. 115.

${ }^{24}$ Ibidem, s. 114. 
O tym, że w obliczu konfliktu dwóch obowiązków warunkowych podmiot ma obowiązek bezwarunkowy wyboru jednej z opcji niech świadczy fakt zaciągania na siebie przewiny moralnej kogoś, kto pozostaje bierny. Z przewiną wiąże się dla podmiotu doznawanie takich negatywnych uczuć jak żal i skrucha. Jest to spowodowane niesprostaniem pewnym wymaganiom moralnym, które domagały się realizacji. Jednak żal i skrucha moga pojawić się także u osoby, która dokonała wyboru i zrealizowała jedną ze skonfliktowanych powinności. Odczuwanie żalu u takiej osoby również jest zrozumiałe, bo i ona nie odpowiedziała na narzucającą się powinność. Intensywność tych uczuć jest jednak mniejsza, bo kiedy podmiot racjonalizuje swój wybór, wie, że zrobił wszystko, co było w jego mocy.

Cokolwiek podmiot zrobi — wybierze jedną z opcji czy pozostanie bierny — będzie odczuwał żal i skruchę. Nie jest to więc rodzaj sytuacji, z której można wyjść zwycięsko. Kiedy się jednak wybierze jedną z opcji, przestaje się być na pozycji zupełnie przegranej. Brink kreśli w tym miejscu paralelę do sytuacji Osła Burdiana, który umiera z głodu, choć stoją przed nim dwa żłoby pełne siana, ponieważ nie może zdecydować, czym się kierować przy wyborze raczej jednego żłobu przed drugim $^{25}$. Wybór pozwala opuścić pozycję przegranego, choć nie jest to wybór w pełnym tego słowa znaczeniu, ponieważ nie można się odnieść do racjonalnego kryterium. Pozostają pozaracjonalne preferencje, a nawet postawienie na ślepy los — najważniejsze, żeby zrealizować choć minimum z tego, co da się w kwestii powinności moralnej. W tym sensie danie komuś, kto jest rozdarty wewnętrznymi wątpliwościami, rady „nieważne co, ale coś wybierz”, jest cenną wskazówką do działania. Jest to kolejny powód do uznania aglomeracji w osłabionej postaci za równoprawną zasadę moralną.

Zasada aglomeracji w osłabionej postaci, choć z inspiracji Brinka, jednak dla innych celów została przyjęta do systemu LP, aniżeli przyjmował ją Brink. Brink powoływał się na nią, aby wykluczyć z dyskursu moralnego dylematy. W systemie LP pozwala radzić sobie z sytuacjami konfliktowymi bez popadania w sprzeczność. Kiedy z dwóch powinności osobno wnosimy o ich alternatywnym charakterze w powiązaniu, wówczas immunizujemy system logiczny przeciw sprzeczności w momencie, kiedy pojawią się dwie skonfliktowane powinności. Co jednak ciekawe, kiedy dwie powinności nie są skonfliktowane, alternatywa umożliwia, by powinne było ich wykonanie zarazem. W takim wypadku wybór nie jest konieczny.

Zasada osłabionej aglomeracji nie dość, że uodparnia system logiki powinności na sprzeczność, jeśli dołączyć do niego warunki dylematu, to nie jest — jak widzimy - jedynie w tym celu przyjętym aksjomatem, ale ma również swoje racje natury filozoficznej. Jest znaczącą zasadą, jeśli chodzi o działanie moralne. W sytuacji dylematu mówi „powinieneś wybrać”. Można w związku z tym postawić zarzut, że jest to zbyt silne założenie, aby uznać je za prawo logiczne. Logika deontyczna ma za zadanie odkrywać logiczną strukturę pojęcia obowiązku, a nie dawać rady, jak postępować w sytuacjach praktycznych wyborów. Zarzut ten jednak można odeprzeć, jeśli rozważyć, na ile jest to abstrakcyjna zasada. Powiada: z dwóch powinności osobno, co najmniej jedna jest powinna, kiedy je zestawić razem. Kiedy

${ }^{25}$ Ibidem, s. 116. 
nie ma dylematu, podmiot spełnia oba, a kiedy nie jest to możliwe, spełnia choć jeden. I tyle. Gdyby mówiła, co wybrać, jak wybrać, kiedy itp., wówczas zarzut byłby zasadny. Zasada ta mówi jedynie w kwestii dylematu „wybierz!”. Tyle i tylko tyle można odczytać z formalnej struktury samego pojęcia powinności.

(8) Dalej przejdę do opisu systemu $\mathrm{LP}_{\mathrm{D}}$ od strony semantycznej. Naszkicuję w skrócie twierdzenie o pełności dla tego systemu. Dysponując twierdzeniem o pełności, łatwo można będzie wykazać, które niepożądane ze względu na dylematy formuły nie są twierdzeniami $\mathrm{LP}_{\mathrm{D}}$, a tym samym, jak system ten spełnia wymogi wyzwania Goble'a.

Ponieważ system $\mathrm{LP}_{\mathrm{D}}$ jest logiką słabszą od logik zarówno normalnych (brak wśród reguł inferencji reguły ukonieczniania), jak i regularnych (brak reguły regularności), dlatego do jego semantycznej charakterystyki zostanie użyta semantyka otoczeniowa. Nie wchodząc w szczegóły, strukturą otoczeniową F jest para uporządkowana $<\mathrm{W}, \mathrm{N}>$, gdzie $\mathrm{W}$ jest niepustym zbiorem światów możliwych, a $\mathrm{N}$ jest funkcją przyporządkowującą każdemu elementowi zbioru W pewną rodzinę podzbiorów zbioru W, zwanych jego otoczeniami. Modelem otoczeniowym $\mathrm{M}$ języka $\mathrm{L}$ jest para uporządkowana $\langle\mathrm{F}, \mathrm{V}\rangle$, gdzie $\mathrm{F}$ jest struktura otoczeniową $<\mathrm{W}, \mathrm{N}>$, a $\mathrm{V}$ jest funkcją przypisującą każdej literze zdaniowej języka L podzbiór zbioru W.

Relację spełniania formuł języka L w modelu M definiujemy standardowo. Niech M będzie dowolnym modelem otoczeniowym zdefiniowanym jak wyżej, wówczas dla dowolnego u należącego do W:

(i) $(\mathrm{M}, \mathrm{u}) \vDash \mathrm{p}$ wtw. $\mathrm{u} \in \mathrm{V}(\mathrm{p})$, gdzie p jest dowolną literą zdaniową,

(ii) $(\mathrm{M}, \mathrm{u}) \vDash \sim \alpha$ wtw. nieprawda, że $(\mathrm{M}, \mathrm{u}) \vDash \alpha$,

(iii) $(\mathrm{M}, \mathrm{u}) \vDash \alpha \rightarrow \beta$ wtw. jeśli $(\mathrm{M}, \mathrm{u}) \vDash \alpha$, to $(\mathrm{M}, \mathrm{u}) \vDash \beta$,

(iv) $(\mathrm{M}, \mathrm{u}) \vDash \alpha \vee \beta$ wtw. $(\mathrm{M}, \mathrm{u}) \vDash \alpha \operatorname{lub}(\mathrm{M}, \mathrm{u}) \vDash \beta$,

(v) $(\mathrm{M}, \mathrm{u}) \vDash \alpha \wedge \beta$ wtw. $(\mathrm{M}, \mathrm{u}) \vDash \alpha \mathrm{i}(\mathrm{M}, \mathrm{u}) \vDash \beta$,

(vi) $(\mathrm{M}, \mathrm{u}) \vDash \alpha \vee \beta$ wtw. $(\mathrm{M}, \mathrm{u}) \vDash \alpha$ wtedy i tylko wtedy, gdy $(\mathrm{M}, \mathrm{u}) \vDash \beta$,

(vii) $(\mathrm{M}, \mathrm{u}) \vDash \mathrm{O} \alpha$ wtw. $[\alpha]^{\mathrm{M}} \in \mathrm{N}(\mathrm{u})$,

gdzie $[\alpha]^{M}=\{u \in W:(M, u) \vDash \alpha\}$.

Dla dowolnego świata $\mathrm{u}$ oraz zbiorów światów X i Y modelu M przyjmijmy następujące warunki dla funkcji $\mathrm{N}$ :

(w1) jeśli $X \in N(u) i-(X \cap Y) \in N(u)$, to $-Y \in N(u)$,

(w2) jeśli $X \in N(u)$ i $Y \in N(u)$, to $X \cap Y \in N(u)$,

(w3) jeśli $X \cap Y \in N(u)$, to $X \in N(u)$ lub $Y \in N(u)$.

Łatwo dowieść, że system $\mathrm{LP}_{\mathrm{D}}$ jest pełny względem klasy struktur otoczeniowych $\mathrm{F}=\langle\mathrm{W}, \mathrm{N}\rangle$, które spełniają warunki (w1)-(w3). Dzięki warunkowi (w1) spełniony jest aksjomat (K), dzięki warunkowi (w2) spełniony jest aksjomat $\left(\mathbf{A P}^{*}\right)$, a warunkowi (w3) odpowiada aksjomat $\left(\mathbf{M}^{*}\right)$. Spełnianie (RE) nie wymaga przyjęcia żadnego dodatkowego warunku.

System $\mathrm{LP}_{\mathrm{D}}$ unika sprzeczności i deontycznej eksplozji, czyli spełnia warunek niesprzeczności i nietrywialności spośród warunków wyzwania Goble’a. Aby się o tym przekonać, wystarczy pokazać, że twierdzeniami $\mathrm{LP}_{\mathrm{D}}$ nie są odpowiednio formuły (D) i (DEX). W tym celu rozważmy model $\mathrm{M}^{*}=\langle\mathrm{W}, \mathrm{N}, \mathrm{V}\rangle$, gdzie $\mathrm{W}=\{\mathrm{u}, \mathrm{v}, \mathrm{t}\}, \mathrm{N}(\mathrm{u})=\{\{\mathrm{u}, \mathrm{v}\},\{\mathrm{t}\}, \varnothing, \mathrm{W}\}, \mathrm{N}(\mathrm{v})=\mathrm{N}(\mathrm{t})=\{\varnothing, \mathrm{W}\}$, a wartościo- 
wanie przyjmuje postać: $\mathrm{V}(\mathrm{p})=\{\mathrm{u}, \mathrm{v}\}, \mathrm{V}(\mathrm{q})=\{\mathrm{v}, \mathrm{t}\}, \mathrm{V}(\mathrm{s})=\mathrm{W}$, dla pozostałych liter zdaniowych s. Łatwo przekonać się o tym, że model $\mathrm{M}^{*}$ spełnia warunki (w1)-(w3), jest więc modelem system $\mathrm{LP}_{\mathrm{D}}$. W modelu $\mathrm{M}^{*}:\left(\mathrm{M}^{*}, \mathrm{u}\right) \vDash \mathrm{Op},\left(\mathrm{M}^{*}\right.$, $\mathrm{u}) \vDash \mathrm{O} \sim \mathrm{p} \mathrm{i}\left(\mathrm{M}^{*}, \mathrm{u}\right) \not$ Oq. Ze względu na $\left(\mathrm{M}^{*}, \mathrm{u}\right) \vDash \mathrm{Op},\left(\mathrm{M}^{*}, \mathrm{u}\right) \vDash \mathrm{O} \sim \mathrm{p}$, prawda nie jest formuła $(\mathbf{D})$, natomiast ze względu na $\left(\mathrm{M}^{*}, \mathrm{u}\right) \vDash \mathrm{Op},\left(\mathrm{M}^{*}, \mathrm{u}\right) \vDash \mathrm{O} \sim \mathrm{p}$ $\mathrm{i}\left(\mathrm{M}^{*}, \mathrm{u}\right) \not \neq$ Oq, prawdac w modelu $\mathrm{M}^{*}$ nie jest formuła (DEX).

System $\mathrm{LP}_{\mathrm{D}}$, choć jest na tyle słaby, aby nie były jego twierdzeniami formuły (D) i (DEX), jest jednak na tyle silny, aby uprawomocniać rozumowania typu argument Smitha. Tezą $\mathrm{LP}_{\mathrm{D}}$ jest bowiem formuła $(\mathrm{O}(\alpha \vee \beta) \wedge \mathrm{O} \sim \alpha) \rightarrow \mathrm{O} \beta$, dlatego z warunków $\mathrm{O}(\alpha \vee \beta)$ i $\mathrm{O} \sim \alpha$ możemy przejść do $\mathrm{O} \beta$ na mocy reguły odrywania (MP).

\section{Bibliografia}

Brink D.O., Moral Conflict and Its Structure, [w:] Moral Dilemmas and Moral Theory, H.E. Mason (ed.), New York-Oxford 1996, s. 102-126.

Chyrowicz B., O sytuacjach bez wyjścia w etyce. Dylematy moralne: ich natura, rodzaje i sposoby rozstrzygania, Kraków 2008, s. 176-207.

Goble L., A Logic for Deontic Dilemmas, „Journal of Applied Logic” 3 (2005), s. 461-483. Goble L., Normative Conflicts and The Logic of „Ought”, „Noûs” 43 (2009), s. 450-489. Marcus R.B., Moral Dilemmas and Consistency, [w:] Moral Dilemmas, Ch.W. Gowans (ed.), New York-Oxford 1987, s. 188-204.

Mothersill M., The Moral Dilemmas Debate, [w:] Moral Dilemmas and Moral Theory, H.E. Mason (ed.), New York-Oxford 1996. s. 66-85.

Williams B., Spójność etyczna, tłum. M. Szczubiałka, [w:] idem, Ile wolności powinna mieć wola? I inne eseje z filozofii moralnej, tłum. T. Baszniak, T. Duliński, M. Szczubiałka, Warszawa 1999, s. 89-114. 